\title{
Foreign Direct Investment, Business Environment and Economic Growth in Sub-Saharan Africa: Pooled Mean Group Technique
}

\section{Abdelbagi Edrees*}

Universiti Putra Malaysia, Serdang, Selangor Darul Ehsan, Malaysia

\begin{abstract}
This study examined the role played by foreign direct investment and business environment on economic growth. The sample contained 39 Sub-Saharan African countries divided into two groups, 21 low incomes and 18 middle incomes from 1992 to 2012. The findings of pooled mean group estimator (PMG) revealed that the impact of foreign direct investment on economic growth was negative and statistically significant in low income and middle income countries. This result implies that more foreign direct investment harms economic growth in Sub-Saharan Africa. In addition, the business environment appeared to have different impact on economic growth with respect to the income level.
\end{abstract}

Keywords: FDI; Business environment; Economic growth; Pooled mean group

\section{Introduction}

The impact of foreign direct investment (FDI) on economic growth is a well-investigated issue by many economists over around the world especially in the developed countries, while it is less-studied especially in African countries. Foreign direct investment plays an important role in the performance of the economy as a whole. The FDI is expected to have spillover effects among all sectors in the economy of the host country, such as increasing the export of goods and services, importing advance technology, adopting new advanced production processes, decreasing the rate of unemployment by the job creation and increasing the fund and finance for the local investors. These spillover effects could be much higher in a particular business environment such as improved infrastructure stock, high level of human capital and developed financial sector $[1,2]$.

The foreign direct investment inflows in Africa is the lowest comparing to other regions, even it increased in recent decades but still lower in the world [3]. Attracting more FDI flows to come-in the region needs more improvement in the business environment such as human capital and infrastructure to gain more advantages from the FDI spillover effects [4,5]. Business environment in African countries is inadequate, since the infrastructure stock and human capital are too low comparing to other regions (See doing business report 2013). Recent reports show that only $27 \%$ of African population has access to internet, $22 \%$ of African population is telephone subscribers, transportation cost in Africa is the highest in the world and access to electricity in Africa is the lowest in the world [3].

It is most important thing to understand the nature of the impact of FDI and business environment on economic growth. The recent studies are less-focused in African countries, for example [6-13] studied the relationships of interest in different regions, while the studies in Africa are quite rare. So it is very important to fill the gap in addressing this issue in Africa to help policy-makers to develop and introduce effective polices to grow the economy of the region. From this end, the aim of this study is to examine the relationships between foreign direct investment, business environment and economic growth.

The rest of the paper organized as follows. Section 2 literature review, Section 3 outlines our empirical strategy, which encompasses specifying an appropriate dynamic model, econometrics method and describes the various data sets that are utilized in the methodology.
Section 4 reports and discusses the econometric results, reports robustness checks, makes comparisons to related literature. Finally, Section 5 summary and conclusion.

\section{Literature Review}

The ideas that FDI led economic growth, business environment positively contribute to economic growth remains extremely controversial. This could be due to the use of different samples by different researchers, or due to the problem associated with the methodology used in each study or to the differences in the economy's characteristics in each single country.

Theoretically, economic growth is a well-studied issue. The role of technological progress has been included in the production function as a determinant of the growth by [14] that is devoted a model of longrun growth to include the price-wage-interest reactions, interest-elastic savings schedule and allowed for the neutral technological change. Extend the Solow model to include the human capital accumulation through years of schooling in the production function [15]. Closely following the work of Solow, Lucas examined the interaction of physical and human capital accumulation on growth. The inclusion of the education human capital in the growth model continued in the work of [16-18] and expanded to include the health human capital in the production function as an important determinant of economic growth [19-21]. In-other side, there are two main theories in the impact of investment on growth which are the Modernization theory and the Dependency theory. The Modernization theory insists that the Third World is underdeveloped and remains in such a state because of its historical failure to industrialize and modernize with technology, the theory consider the lack of the finance as a one of the reasons associated with the failure of those countries. One of the solutions provided by this theory is the foreign direct investment which assumed to have positive impact on economic growth. The Dependency Theory

*Corresponding author: Abdelbagi Edrees, Universiti Putra Malaysia, Serdang, Selangor Darul Ehsan, Malaysia, Tel: +60 3-89466000; E-mail: a.abdelbagi@hotmail.com

Received April 13, 2015; Accepted May 18, 2015; Published May 27, 2015

Citation: Edrees A (2015) Foreign Direct Investment, Business Environment and Economic Growth in Sub-Saharan Africa: Pooled Mean Group Technique. J Glob Econ 3: 144. doi:10.4172/2375-4389.1000144

Copyright: (c) 2015 Edrees A. This is an open-access article distributed under the terms of the Creative Commons Attribution License, which permits unrestricted use, distribution, and reproduction in any medium, provided the original author and source are credited. 
however, is opposed to all the assessments and solutions offered by the Modernization Theory. The Dependency Theory argues that the plight of the Third Worlds as a result of the rapid economic growth and economic development in the First World countries. Thus, the theory believes-in the negative effects of the foreign direct investment on the economic growth $[22,23]$.

Empirically, the impact of FDI on growth is subject to the level of existing business environment in the host country. For-instance, [11] found that FDI by itself have a positive significant impact on growth but countries with well-developed financial market benefits more from FDI. The pervious finding has been confirmed by [1] they resulted that the positive impact of FDI on economic growth kicks-in only after financial market development exceeds a threshold level, until then the benefits of FDI is non-existent. Moreover, FDI by itself can contribute positively to economic growth and its impact is not subject to a particular environment $[4,24]$. Moving-forward, the impact of FDI on growth has found to be insignificant in the short-run and the long run as well [2]. A different view has been added to the previous results, which is that FDI have a negative impact on economic growth $[25,26]$, they justified their finding due to the technology-gap and poor business environment in the countries of interest. Moreover, [27] found a bi-directional relationship between foreign direct investment and economic growth in 13 selected MENA countries.

Human capital and infrastructure are playing an important role in the development of the economy. Improving the infrastructure quality and quantity such as advanced technology, roads and telecommunication services causes more power in the economic performance. In fact, investment in roads and transportation system reduces the cost associated with trade and increases the competitiveness of the firms and companies in the global market [9,28-31]. Nonetheless, healthy and educated labor force contribute positively to economic growth [32], while investment in education and health care enhances the productivity of individuals and increases the total production in the economy $[16,33]$. Moreover, it is now widely accepted that human capital and infrastructure are important determinants of economic growth. They may affect growth directly by themselves or indirectly through attracting FDI flows and contribute to the growth [7,34-36].

Among these studies only $[4,26,37,38]$ has focused on African countries. Due to the differences in the outcomes of the literature reviewed above and the lack of studies focused on African countries, it is much important to investigate the relationships among foreign direct investment, business environment and economic growth in Africa.

\section{Empirical Models and Methodology}

\section{The growth equation}

Following the contribution of [14-20] and other economists in developing the new growth theory and to search for a set of variables for modeling the growth, a degree of convergence on the most empirical specification has occurred. The explanatory variables for economic growth in those studies are identified to include population, domestic investment, foreign investment, human capital and infrastructure stock [8,20,39-41]. The growth model in this study is therefore:

$\ln G D P_{\text {it }}=\beta_{0}+\beta_{1} \ln F D I_{\text {it }}+\beta_{2} \ln H_{\text {it }}+\beta_{3} \ln I F_{\text {it }}+\beta_{4} \ln K_{\text {it }}+\beta_{5} \ln L_{\text {it }}+\mu_{\text {it }}(1)$

where GDP is the real GDP, FDI is foreign direct investment, $\mathrm{H}$ is human capital, IF is infrastructure, $\mathrm{K}$ is physical capital, $\mathrm{L}$ is total labor force, $\mu$ is the error term, $\beta_{0}, \beta_{1}, \beta_{2}, \beta_{3}, \beta_{4}$ and $\beta_{5}$ are the parameters to be estimated, $i$ refers to the country while $t$ refers to the year. Equation
(1) tells that real GDP is determined by the variables of interest which include foreign direct investment $F D I$, human capital $H$, infrastructure $I F$, gross capital formation $K$ and total labor force $L$.

\section{Pooled mean group technique}

According to Pesaran and Smith [42] the traditional estimators such as fixed-effects, random-effects and generalized method of moments GMM can lead to inconsistent estimates in the long-run due to the slope heterogeneity bias. The PMG is introduced by Pesaran et al. [43] to overcome this problem associated with those estimators. One advantage of the PMG is that it allows for the short-run dynamic specification to vary across countries, while the long-run coefficients are constrained to be the same.

\section{The data}

The study is using a panel of 39 Sub-Saharan Africa countries which divided into two groups of income levels, namely, 21 low income countries and 18 middle income countries in a period time from 1992 to 2012. The data used is obtained from World Development Indicators and African Union. The variables used in this study are real GDP, FDI as a percentage of GDP human capital proxies by secondary school enrollment, the infrastructure $(I F)$ proxied by access to electricity as a percentage of population, gross capital formation $(K)$ and total labor force $(L)$. Table 1 shows the descriptive statistic of our variables in the full sample countries (Table 1).

\section{Empirical Results}

\section{Panel unit root test}

The variables are tested for unit root in level including intercept and time trend and after taking first difference including only intercept. The lag length is determined according to Schwarz information criterion SIC. Table 2 shows the results of Im et al. IPS and Levin et al. [44,45], LLC unit root tests for low income and middle income Sub-Saharan African countries. The findings for low income countries show that $\ln F D I, \ln H, \ln K$ and $\ln L$ are stationary in level indicating that the variables are $I(0)$ However, $\ln I F$ have unit root in level, but it is stationary after taking the first difference. In addition, IPS and LLC show conflicting results for $\ln G D P$ in level, but both tests reveal that the variable stationary after the first difference. This enables us to conclude that all the variables for low income Sub-Saharan African countries are either $I(0)$ or $I(1)$. For middle income countries, both test reveal that $\ln F D I, \ln K$ and $\ln L$ are stationary variables or $I(0)$. On the other hand, $\ln H$ and $\operatorname{lnIF}$ are stationary only after first difference. While, $\ln G D P$ is shown to have a contradictory result in level, however, it becomes stationary after taking first difference. Although, the IPS and LLC tests show contradictory findings about $\ln G D P$ 's order of integration, it can be considered as $I(1)$ to avoid the statistical consequences of treating $I(1)$ variable to be $I(0)$. Therefore, the general conclusion of the panel

\begin{tabular}{|c|c|c|c|c|}
\hline & Mean & Std. Dev. & Min & Max \\
\hline GDP & 1.43 & 4.09 & 1.26 & 4.02 \\
\hline $\boldsymbol{F D I}$ & 4.93 & 11.48 & -82.89 & 161.8 \\
\hline $\boldsymbol{H}$ & 35.88 & 24.43 & 2.20 & 122.2 \\
\hline $\boldsymbol{I} \boldsymbol{F}$ & 30.92 & 21.52 & 4.4 & 99.5 \\
\hline $\boldsymbol{K}$ & 2.64 & 7.20 & 11.12 & 7.83 \\
\hline $\boldsymbol{L}$ & 6130358 & 8514110 & 35876 & 52642336 \\
\hline
\end{tabular}

Note: $G D P$ and $K$ are in billion USD, $F D I$ is in percentage of $G D P$, IF is in percentage of total population, and $L$ is total labor force.

Table 1: Descriptive statistic. 


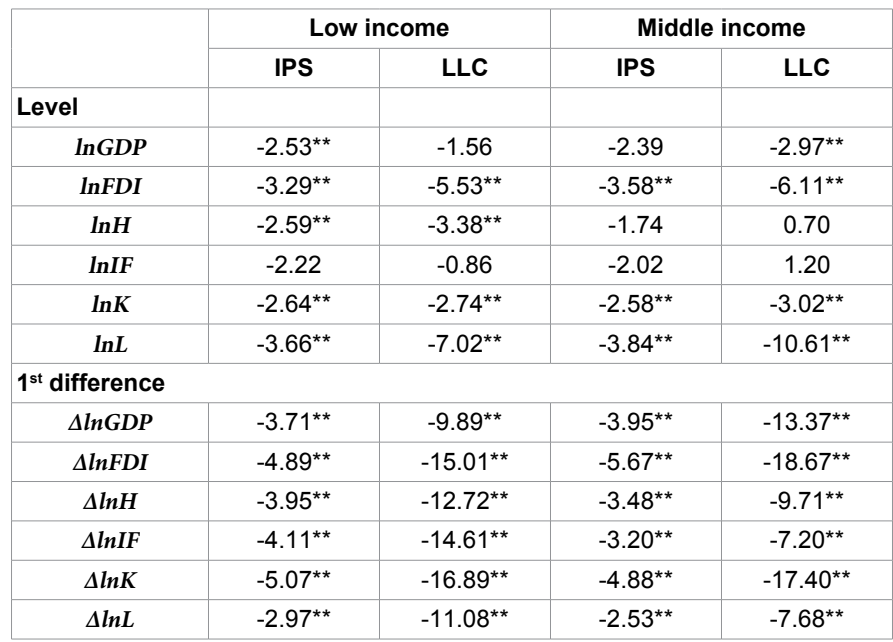

Note: **indicates significant at $5 \%$. At level, intercept and trend are included, but in $1^{\text {st }}$ difference only intercept is included. Thelag length selected based on SIC.

Table 2: Panel unit root tests.

\begin{tabular}{|l|c|c|c|c|}
\hline \multirow{2}{*}{} & \multicolumn{2}{|c|}{ Low income } & \multicolumn{2}{c|}{ Middle income } \\
\cline { 2 - 5 } & PP-Stat & ADF-Stat & PP-Stat & ADF-Stat \\
\hline Within-dimension & $-4.09^{\star *}$ & $-4.98^{\star *}$ & $-1.87^{\star *}$ & $-2.13^{\star *}$ \\
\hline Between-dimension & $-8.13^{\star *}$ & $-7.91^{\star *}$ & $-3.89^{\star *}$ & $-3.33^{\star *}$ \\
\hline
\end{tabular}

Note: **indicates significant at $5 \%$. The results withinterceptand no trend.Lag length selection based on SIC.

Table 3: Pedroni co-integration test.

unit root test for low income and middle income countries is that the variables are $I(0)$ or $I(1)$.

\section{Co-integration test}

The following step after we identify the order of integration among variables is to examine the existence of co-integration relationship between the variables. The study employs [46] test to show that the variables move together in the long run. Table 3 presents Pedroni co-integration test findings for PP-statistics and ADF-statistics for between and within groups, respectively. The findings of co-integration test provide evidence of long run relationship between variables for low income and middle income countries. This enables us to estimate the long run and short run coefficients using pooled mean group estimation technique.

\section{Pooled mean group}

Table 4 shows the findings of pooled mean group PMG for low income and middle income Sub-Saharan African countries. First, for low income countries the long run results show that FDI have a negative significant impact on economic growth. This implies that any increase of FDI inflows will lead to further reduction in GDP growth. Moreover, the impact of human capital $\ln H$ is found to be positive and statistically significant at $1 \%$, indicating that any improvement in GDP is attributable to human capital enhancement. Likewise, the impact of physical capital $\ln K$ on economic growth appears to be very important since the coefficient is positive and significant. However, the impact of infrastructure $\ln I F$ and labor $\ln L$ is positive but insignificant in explaining economic growth. The error correction model (ECM) reveals that the error correction term (ECT) is negative and significant. This confirms the co-integration relationship according to Engle and Granger [47] representation theorem. In addition, the ECT incorporates the long run information and shows the speed of adjustment. Particularly, it shows that any deviation from the long run expected value is adjusted by $42.3 \%$ annually. The FDI and infrastructure have insignificant impact on economic growth in the short run. In contrary, the impact of human capital is negative and significant at $10 \%$, whereas, the physical capital and labour are positively related to GDP in the short run.

Second, the PMG results for middle income countries indicate that the FDI is negatively associated with economic growth in the long run. This finding is similar to the one of low income countries shown in the second column of Table 4. In contrary, the impact of human capital $\ln H$ appears to be insignificant in middle income countries. Likewise, the infrastructure $\ln I F$ is positive and significant variable in economic growth function. This finding emphasizes the role played by infrastructure improvement in stimulating economic growth In addition, the impact of physical capital on GDP is positive and significant. This shows the importance of physical capital accumulation in enhancing economic growth in Sub-Saharan Africa. The findings of the error correction model (ECM) reveal that the error correction term (ECT) is negative and significant, and it shows that the pervious disequilibrium is corrected by $27.7 \%$ annually. The infrastructure $\Delta \operatorname{lnINF}$ and capital $\Delta \ln K$ are the only significant variables in the short run.

\begin{tabular}{|c|c|c|}
\hline & Low income & Middle income \\
\hline \multicolumn{3}{|l|}{ Long run model } \\
\hline $\ln F D I$ & $-0.682^{*}(0.380)$ & $-0.189^{\star * \star}(0.048)$ \\
\hline $\ln H$ & $0.851^{\star \star \star}(0.063)$ & $0.013(0.079)$ \\
\hline $\ln I F$ & $0.046(0.064)$ & $0.802^{\star \star \star}(0.152)$ \\
\hline $\ln K$ & $0.227^{\star * \star}(0.024)$ & $0.762^{* \star *}(0.039)$ \\
\hline $\ln L$ & $0.185(0.178)$ & $0.018(0.210)$ \\
\hline \multicolumn{3}{|l|}{ Short run model } \\
\hline$\Delta \ln F D I$ & $-0.002(0.005)$ & $-0.043(0.038)$ \\
\hline$\Delta \ln H$ & $-0.401^{*}(0.216)$ & $0.212(0.242)$ \\
\hline$\Delta \ln I F$ & $-0.214(0.212)$ & $-1.668^{*}(1.006)$ \\
\hline$\Delta \ln K$ & $0.133^{\star \star *}(0.036)$ & $0.229^{\star * *}(0.055)$ \\
\hline$\Delta \ln L$ & $3.818^{*}(2.137)$ & $-1.891(2.646)$ \\
\hline$E C T_{t-1}$ & $-0.423^{* * *}(0.087)$ & $-0.277^{* * *}(0.049)$ \\
\hline C & $6.171^{* * *}(1.243)$ & $-1.120^{* * *}(0.185)$ \\
\hline Log Likelihood & 465.5 & 419.8 \\
\hline Hausman test $p$-value & 0.36 & 0.82 \\
\hline
\end{tabular}

Note: ${ }^{* * *},{ }^{* *}$ and ${ }^{*}$ indicates significant at $1 \%, 5 \%$ and $10 \%$, respectively. Between () are the standard errors. The ARDL model $(1,1,1,1,1$ and 1$)$ used uniform lags. Table 4: Pooled mean group results.

\begin{tabular}{|c|c|}
\hline Variable & Coefficient \\
\hline $\ln G D P_{t-1}$ & $0.709^{* * *}(0.018)$ \\
\hline $\ln F D I$ & $-0.030^{* \star *}(0.005)$ \\
\hline $\ln H$ & $-0.048(0.040)$ \\
\hline $\ln I F$ & $0.033(0.049)$ \\
\hline $\ln K$ & $0.312^{* * *}(0.011)$ \\
\hline $\ln L$ & $0.015(0.021)$ \\
\hline AR (1): p-value & 0.01 \\
\hline AR (2): p-value & 0.49 \\
\hline Sargan test: $p$-value & 0.20 \\
\hline Instruments & 28 \\
\hline
\end{tabular}

Note: ${ }^{* * *}$ indicates significant at $1 \%$. Between ( ) are t-statistics. Three years average has been taken. Time dummy which is significant did not include in the table. Table 5: System-GMM results. 
Our results are in line with part of the finding of Gui-Diby who found that the impact of FDI on growth in Africa was negative in the period time from to 1980 to 1994 and positive insignificant during the period from 1995 to 2009. The differences between our findings and the findings of Gui-Diby absolutely due to the different methodology used in each study, our study used the PMG technique and Gui-Diby used GMM technique. Due to the less observations in the GMM estimation, the results could be bias and then the issue cannot be completely addressed by using GMM. We believe that the impact of FDI on growth is subject to a particular environment and the host country could benefit more positive FDI spill-over effects if they improved infrastructure which facilitates the doing business in the country and reduces the cost associated with trade. In addition, high human capital level helps in the issue of innovation and adopting new production procedures and reduces the marginal cost of production, those particular environment are helping the economy to gains more from the foreign direct investment inflows. Thus, due to the poor human capital and infrastructure in Africa Gui-Diby our results are quite acceptable and the impact of FDI on economic growth is negative. In such cases like the existence of the poor human capital, the foreign investors need to import the trained and skilled workers, then the existing unemployment's rate will remain the same, therefore, the assumption of the positive spill-over effect of FDI by the job creation is not applicable in African counties. Moreover, the outflows remittances by those imported workers will increase, which may support the negative impact of FDI on growth in Africa.

The results found that education human capital have positive significant long-run impact on growth in the low income group; this finding is in line with [48] and others. This reveals that African governments in this group should invest more in education to gain more significant impact onto the growth. Nonetheless, the impact of infrastructure on growth in low income group is not significant and it is significant on growth in middle income countries. Hence, the differences between the economy's structure in the two income groups is big, then the importance of the infrastructure is therefore differs from group to other, since the agricultural economy in SubSaharan low income countries is not depending on the availability of the electricity then the insignificant impact of access to electricity on growth is therefore logically acceptable. Once the economies in the middle income Sub-Saharan African countries are relatively industrial economies compared to the low income countries, thus the importance of the electricity is much bigger in this group which justifies the result that the impact of access to electricity is positive and statistically significant on economic growth.

\section{Robustness check using system GMM estimator for the full sample countries}

To robustness check our main finding we ran a system GMM estimator for the full sample countries, the results of the estimation confirmed that the impact of FDI on economic growth in Sub-Saharan Africa is negative and statistically significant. Thus, our results are robust. Table 5 shows the results of the system GMM estimation.

\section{Conclusion}

This study examined the effects of business environment which proxies by human capital and infrastructure, and foreign direct investment on economic growth in Sub-Saharan Africa. Using annual data for 21 low income countries and 18 middle income countries in time period from 1992 to 2012 and using Pooled Mean Group technique, we found that FDI have negative significant impact on economic growth in-both low and middle income groups. Furthermore, we found that human capital is playing an important role in the economy in the low income group, while infrastructure in middle income group is statistically affects economic growth. Nonetheless, we ran system GMM estimation to robustness check our findings, the results of the GMM confirmed our finding. Thus, our results are robust

\section{References}

1. Azman-Saini WNW, Law SH, Ahmad AH (2010) FDI and economic growth: New evidence on the role of financial markets. Economics Letters 107: 211-213.

2. Herzer D, Klasen S, Nowak-Lehmann DF (2008) In search of FDI-led growth in developing countries: The way forward. Economic Modelling 25: 793-810.

3. African Union (2013) African economy outlook.

4. Gohou G, Soumaré I (2012) Does Foreign Direct Investment Reduce Poverty in Africa and are There Regional Differences? World Development 40: 75-95.

5. Yamin M, Sinkovics RR (2009) Infrastructure or foreign direct investment? An examination of the implications of MNE strategy for economic development. Journal of World Business 44: 144-157.

6. Shi H, Huang S (2014) How Much Infrastructure Is Too Much? A New Approach and Evidence from China. World Development 56: 272-286.

7. Zhang C, Zhuang $L$ (2011) The composition of human capital and economic growth: Evidence from China using dynamic panel data analysis. China Economic Review 22: 165-171.

8. Annabi N, Harvey S, Lan Y (2011) Public expenditures on education, human capital and growth in Canada: An OLG model analysis. Journal of Policy Modeling 33: 852-865.

9. Pradhan RP, Bagchi TP (2013) Effect of transportation infrastructure on economic growth in India: The VECM approach. Research in Transportation Economics 38: 139-148.

10. lanchovichina $E$ (2013) Job Creation through Infrastructure Investment in the Middle East and North Africa. World Development 45: 209-222.

11. Alfaro L (2004) FDI and economic growth: the role of local financial markets. Journal of International Economics 64: 89-112.

12. Almfraji MA, Almsafir MK, Yao L (2014) Economic Growth and Foreign Direct Investment Inflows: The Case of Qatar. Procedia - Social and Behavioral Sciences 109: 1040-1045.

13. Sbia R, Shahbaz M, Hamdi H (2014) A contribution of foreign direct investment clean energy, trade openness, carbon emissions and economic growth to energy demand in UAE. Economic Modelling 36: 191-197.

14. Solow R (1956)A Contribution to the Theory of Economic Growth. The Quarterly Journal of Economics 70: 65-94.

15. Lucas RE (1988) On The Mechanics of Economic Development. Journal of Monetary Economics 22: 3-42.

16. Romer (1990a) Endogenous Technological Change. Journal of political economy.

17. Romer (1990b) Human capital in a structural model of economic growth Palgrave Macmillan 25: 131-151.

18. Barro (1991) Economic Growth in a Cross Section of Countries. The Quarterly Journal of Economics 106: 407-443.

19. Barro RJ (1992) Human Capital and Economic Growth.

20. Barro R (2013) Health and Economic Growth. Annals of Economics and Finance 14: 329-366.

21. Wang, Eric C (2002) Public infrastructure and economic growth: a new approach applied to East Asian economies 24: 411-435.

22. John J (2002) Development Theories.

23. Adams S (2009) Foreign Direct investment, domestic investment, and economic growth in Sub-Saharan Africa. Journal of Policy Modeling 31: 939-949.

24. Kottaridi C, Stengos T (2010) Foreign direct investment, human capital and non-linearities in economic growth. Journal of Macroeconomics 32: 858-871.

25. Li X, Liu X (2005) Foreign Direct Investment and Economic Growth: An 
Citation: Edrees A (2015) Foreign Direct Investment, Business Environment and Economic Growth in Sub-Saharan Africa: Pooled Mean Group Technique. J Glob Econ 3: 144. doi:10.4172/2375-4389.1000144

Page 5 of 5

Increasingly Endogenous Relationship. World Development 33: 393-407.

26. Gui-Diby SL (2014) Impact of foreign direct investments on economic growth in Africa: Evidence from three decades of panel data analyses. Research in Economics 68: 248-256.

27. Omri A, Kahouli B (2014) The nexus among foreign investment, domestic capital and economic growth: Empirical evidence from the MENA region. Research in Economics, 68: 257-263.

28. Pradhan RP (2014) Economic growth and the development of telecommunications infrastructure in the G-20 countries: A panel-VAR approach. Telecommunications Policy 38:634-649.

29. Daido K, Tabata K (2013) Public infrastructure, production organization, and economic development. Journal of Macroeconomics 38: 330-346.

30. Francois J, Manchin M (2013) Institutions, Infrastructure, and Trade. World Development 46: 165-175.

31. Moyo B (2013) Power infrastructure quality and manufacturing productivity in Africa: A firm level analysis. Energy Policy 61: 1063-1070.

32. Gyimah-Brempong K, Wilson M (2004) Health human capital and economic growth in Sub-Saharan African and OECD countries. The Quarterly Review of Economics and Finance 44: 296-320.

33. Chi W (2008) The role of human capital in China's economic development: Review and new evidence. China Economic Review 19: 421-436.

34. Colantonio E, Marianacci R, Mattoscio N (2010) On human capital and economic development: some results for Africa. Procedia - Social and Behavioral Sciences 9: 266-272.

35. Esfahani HS, Ramírez MT (2003) Institutions, infrastructure, and economic growth. Journal of Development Economics 70: 443-477.

36. Hochman G, Tabakis C, Zilberman D (2013) The impact of international trade on institutions and infrastructure. Journal of Comparative Economics 41: 126-140.
37. Agbloyor EK (2014) Private capital flows and economic growth in Africa: The role of domestic financial markets. Journal of International Financial Markets Institutions and Money 30: 137-152.

38. Hanushek E (2013) Economic growth in developing countries: The role of human capital. Economics of Education Review 37: 204-212.

39. Prados de la Escosura L, Rosés JR (2010) Human capital and economic growth in Spain. Explorations in Economic History 47: 520-532.

40. Herranz-Loncán A (2007) Infrastructure investment and Spanish economic growth 1850-1935. Explorations in Economic History 44: 452-468.

41. Uddin GS, Sjö B, Shahbaz M (2013) The causal nexus between financial development and economic growth in Kenya. Economic Modelling 35: 701-707.

42. Pesaran MH, Smithb R (1995) Econometrics estimating long-run relationships from dynamic heterogeneous panels 68: 79-113.

43. Pesaran MH, Shin Y, Smith RP (1999) Pooled Mean Group Estimation of Dynamic Heterogeneous Panels.Journal of the American Statistical Association 94: 621-634.

44. Im KS, Pesaran MH, Shin Y (2003) Testing for unit roots in heterogeneous panels. Journal of Econometrics 115: 53-74.

45. Levin A, Lin C, Chu CJ (2002) Unit root tests in panel data : asymptotic and ÿnite-sample properties. Econpapers 108: 1-24.

46. Pedroni $P$ (2004) Panel Cointegration: Asymptotic and Finite Sample Properties of Pooled Time Series Tests With an Application To the Ppp Hypothesis. Econometric Theory 20: 597-625.

47. Granger C, Engle R (1987) Co-Integration and Error Correction : Representation Estimation and Testing.Econometrica 55: 19

48. Oketch MO (2006) Determinants of human capital formation and economic growth of African countries. Economics of Education Review 25: 554-564. 